\title{
The Relationship between Iranian EFL Learners' Self- efficacy Beliefs and Reading Comprehension Ability
}

\author{
Farhad Ghabdian ${ }^{1,2} \&$ Narjes Ghafournia ${ }^{2}$ \\ ${ }^{1}$ Department of English, Khorasan e Razavi Science and Research Branch, Islamic Azad University, Neyshabur, \\ Iran \\ ${ }^{2}$ Department of English, Neyshabur Branch, Islamic Azad University, Neyshabur, Iran
}

Correspondence: Narjes Ghafournia.2 Department of English, Neyshabur Branch, Islamic Azad University, Neyshabur, Iran. E-mail: narjesghafournia@yahoo.com, na.ghafournia@gmail.com. Tel: 09153130060

Received: February 21, 2016

Accepted: March 13, 2016

Online Published: March 17, 2016

doi:10.5430/elr.v5n1p38

URL: http://dx.doi.org/10.5430/elr.v5n1p38

\begin{abstract}
The aim of the present study was to find out whether language learners' self-efficacy beliefs affect the reading comprehension achievement of EFL learners in Iran. A convenience sample of 120 learners from different language schools participated in this study. A self-efficacy questionnaire was adopted to analyze students' self-efficacy beliefs. To measure their reading comprehension, the reading part of Michigan Test, as a test of English language proficiency was adopted and given to the participants. The Pearson product-moment formula demonstrated that there was a significant relation between self-efficacy and reading comprehension, and the correlation between self-efficacy and reading comprehension was positive. Therefore, it might be postulated that the higher self-efficacious the learners are, the better they answer the reading comprehension questions. The results of the statistical analysis also led the researcher to conclude that the relation between language learners' self-efficacy beliefs is not affected by gender.
\end{abstract}

Keywords: Self-efficacy, Reading Comprehension, Language Proficiency

\section{Introduction}

The concept of learners' self-beliefs is a theme having received great attention in education lately. About two decades of inquiry has shown that self-beliefs are powerful factors on academic achievements, which cause a new regard to self-beliefs (Pajares, 2003). "Of all beliefs, self-efficacy is the most influential one, which plays an influential role in determining the choices people make, the effort they persevere in the face of challenge, and the degree of anxiety or confidence they bring to the task at hand" (Bandura, 1986, p. 397). Self-efficacy is defined by Bandura as "people's judgment of their capabilities to organize and execute courses of action required to attain designated types of performance. It is concerned not only with the skills one has but also with the judgments of what one can do with whatever skills one possesses" (p. 391). Delcourt and Kinzie (1993) noted that "perceived self-efficacy reflects an individual's confidence in his or her ability to perform the behavior required to produce specific outcomes" (p. 36).

Studies have shown that efficacy beliefs lead to greater motivation (Graham \& Weiner, 1996; Schunk \& Pajares, 2002), grater behavioral, cognitive, and motivational engagement in the classroom (Linnenbrink \& Pintrich, 2003). Other studies (e.g. Multon, Brown, \& Lent, 1991, Robbins, et al, 2004) also proved the positive effect of efficacious feeling on language performance. Multon, et al (1991) reported a positive effect of self-efficacy on language performance. They indicated that efficacy is more effectual among low achieving learners.

Concerning the strong link between self-efficacy and strategy use, researchers have found a positive relation between strategy use and language performance (Ehrman \& Oxford, 1990; Green \& Oxford, 1995; Rubin, 1975). As students use more strategies, they achieve more success which increases their self-efficacy beliefs. Banduara (1979) stated that previous achievement result in higher sense of self-beliefs.

As Swalander and Taube (2007) maintained "good reading ability is the key to success in educational settings, and this is why researchers try to find effective educational and psychological variables that can explain variations in reading ability and academic achievement" (p. 207). In addition, researchers interested in student motivation and 
learning in academic settings put great emphasis on the position of students' thoughts and beliefs in learning (Schunk, 2003). College students have to learn a large amount of information from English texts. The burden of reading information is mostly related to rote memorization and retention of materials rather than meaningful and deep learning (Lambiotte \& Dansereau, 1992).

Most of students' language learning difficulties are related to their low self-beliefs, which in many cases lead to low motivation, participation, performance and achievement (Pajares, 2003). Additionally, when students judge themselves as capable of managing learning activities confidently, they are more likely to overcome the difficulties they face and achieve the goals they have set (Liang,1998, 2011).Self-efficacy can be responsive to improvements in students' methods of learning and can predict their achievement outcomes (Zimmerman, 2000).

It is a common belief that people with high levels of self-efficacy perform better than those with lower levels of self-efficacy. As stated in literature, students with high level of self-efficacy perform tasks better than those with low level of self-efficacy (Hosenfeld, 1997). So it might be a question whether self-efficacy affects students' performance in language components in particular. Hence, the aim of this study is to investigate the probable significant relation between this salient concept and reading comprehension.

Studies on reading motivation indicate that second language learners, who feel competent and efficacious about reading, are more likely to engage in reading, and their motivation is positively correlated with reading comprehension (Wigfield, \& Guthrie, 1997; Wigfield, et al, 2004). Jalilifar (2010) points out, "despite the growing interest in learning English as a foreign language in Iran, students at the college level seem rarely proficient enough to read and comprehend English language texts" ( $\mathrm{p} 98$ ). Due to Iranian learners' problems in comprehending texts, many of them are reluctant to read English texts, leading to great failure in academic English courses. Hence, the reason for exploring self-efficacy as a variable in this study is that self-efficacy beliefs seem to be closely related to the academic achievement of students (Chapman \& Tunmer, 2003; Pajares \& Valiante, 1997; Schunk, 1991).

The present study seeks to find out whether learners' self-efficacy belief is related to Iranian language learners' reading comprehension achievement. The findings of the present study can shed light on academic reading achievement of second language learners. Recently, there have been many studies carried out to improve the situation of learning/teaching English in Iran (Eslami, \& Fatahi, 2008; Ghonsooly \& Elahi 2011; Rahimi \& Abedini, 2009). Most learners want to get the meaning of a text within printed words, and they are heavily relying on dictionaries. Despite all the efforts, their reading comprehension is still poor, and they lose their interest in reading English texts.

Besides, although there are enough reasons to consider affective issues as powerful variables, which may strongly predict EFL learners' performance, little attempt has been made to examine the variables related to English achievement of Iranian EFL learners. Most of the studies have been done on the effect of self-efficacy on the other skills except for reading (e.g., Ghonsooly, 2003; Ghonsooly \& Ghanizadeh, 2011). Therefore, it seems necessary to investigate the probable significant relation between Iranian English learners' self-efficacy beliefs and their reading comprehension achievement.

\subsection{Objectives of the Study}

The study scrutinized the probable significant relation between Iranian EFL learners' self-efficacy beliefs and their reading comprehension achievement. This study also wants to clarify if there is any significant difference between male and female Iranian EFL learners and their self-efficacy beliefs.

\subsection{Research Questions}

1. Is there any significant relationship between Iranian EFL learners' self-efficacy beliefs and their reading comprehension achievement?

2. Is there any significant difference between male and female Iranian EFL learners and their self-efficacy beliefs?

\subsection{Research Null Hypotheses}

1. There is not any significant relationship between Iranian EFL learners' self-efficacy beliefs and their reading comprehension achievement.

2. There is not any significant difference between male and female Iranian EFL learners and their self-efficacy beliefs. 


\section{Review of Related Literature}

\subsection{A Definition of Self-efficacy}

Self-viability convictions are one way that motivational scientists have conceptualized students' convictions about their own abilities to class work. Self-efficacy beliefs are described by Bandura (1986, p.125) as "people's judgments of their capabilities to organize and execute courses of action required to attain designated types of performances". Pintrich and Schunk, (2002) believed that, the definition of self-efficacy is close to children's perceptions of their competence and their self-concept, which are two terms used in the motivation literature. Self-viability concerns students' convictions in that they can accomplish something such as solving a math issue, reading a book, riding a bike, or tying their shoes. It is concerned with some judgment that the individual can or cannot do about these activities, just as self-perceptions of competence or self-concept beliefs reflecting similar beliefs.

Pintrich and Schunk (2002) also believed that self-esteem includes people's enthusiastic responses to their real achievements, for example, feeling great or awful about themselves in light of the fact that they can or cannot read a book or ride a bike. It is significant that instructors and other school faculty do not mistake self-efficacy with self-esteem. They believed that self-efficacy is distinct from self-concept, which reflects more general beliefs about competence. Self-efficacy beliefs refer to much more particular and situational judgments of abilities.

\subsection{Self-Efficacy Beliefs and ESL/EFL Language Learning}

Although self-efficacy studies on language learning are limited, existing studies have proved a positive relation between key motivational variables like self-efficacy and L2 achievement. Wu et al (2006) believes that students' self-beliefs of their capability to learn a second language are significant factors determining their learning behaviors, endeavor, and persistence. Oxford (1990) asserted that language learners have different competence-related judgments based on their prior learning experiences, and these judgments influence the way they implement a range of learning strategies during the learning process.

One of the most comprehensive studies is the one carried out by Chapman and Tunmer (2003). They investigated the development of achievement-related self-system factors with regard to children's reading achievement. They asserted that reading self-concept and reading self-efficacy appear to develop concerning preliminary experiences in learning to read. They also believed that to deal with skill deficiencies in reading, attention to the improvement of strategies is crucial. Furthermore, to deal with children's negative self-beliefs, use of attribution retraining methods in line with appropriate skills training is useful.

Another study regarding self-efficacy and L2 achievement was carried out by Barkley (2006), who explored if students' perceived self-efficacy beliefs could predict their reading comprehension achievement. A reading comprehension subtest of a state standardized test was utilized to measure reading comprehension of 400 participants, enrolled in a middle school. The results indicated that the students' self-efficacy beliefs about prior knowledge and graphic organizers were positively correlated with their reading comprehension achievement.

Gahungu (2007) studied the relation between self-efficacy and language ability. The participants were 37 college students, studying French at a Midwestern University. The self-efficacy of participants was measured through a 40-item questionnaire, in which they rated the levels of confidence they had in doing language learning tasks.

In a quasi-experimental study, Nevil (2008) investigated the relation between reading self-efficacy and regulation of cognition and reading achievement among 80 students from a rural school in North Central Pennsylvania. The results revealed that reading self-efficacy can predict students' reading achievement. The findings also supported the hypothesis that the students who were more efficacious tend to regulate their cognition at a level significantly different from the students who were less efficacious in reading.

There exist several studies showing the significant effect of learners' self-efficacy on foreign language learning in different language domains (Hsieh \& Schallert, 2008; Hsieh \& Kang 2010; Khajavi \& Ketabi, 2012; Mills, Pajares, \& Herron, 2007, 2006; Tilfarlioğlu \& Cinkara, 2011; Wang, Spencer, \& Xing, 2009).

\subsection{Reading Competence and Self-efficacy}

There are some studies carried out to explore the relation of self-efficacy beliefs in language domains, but only few of them explored the relation between self-efficacy and reading comprehension. In those studies, other variables that may be included are learning strategies, reading attitude, reading anxiety, and gender. As an example, Naseri and Zaferanieh (2012) carried out a study to explore the relation between self-efficacy beliefs, reading strategy use, and reading comprehension of $80 \mathrm{EFL}$ junior and high school students in Iran. The findings showed a significant 
relationship between self-efficacy beliefs and using reading strategies. The students used a variety of reading strategies with cognitive strategies as the most frequently used, followed by test-taking strategies, meta-cognitive, and compensatory strategies. The findings from multiple regression analysis also revealed that the four classifications of reading strategies contribute to the model, suggesting that the increase in the use of four categories of reading strategies would increase reading comprehension. Finally, the findings proved that gender was not a significant variable in relation to self-efficacy beliefs and the implementation of reading strategies.

The study by Sani and Zain (2001) in Malaysia's ESL setting investigated the relationship of reading attitude, self-efficacy and reading ability, and gender differences across the variables. Their study was conducted in an environment that did not encourage the use of English as a second language in Malaysian small town and rural schools because students in those areas use English only for academic purposes. The participants of their study were 200 tenth-graders from two small town schools and three rural schools. They had learned English as a subject since first grade and had been exposed more to English since seventh grade where their teachers used English in addition to Malay as the medium of instruction for math and science.

Sani and Zain (2001) used two questionnaires to measure reading attitude and self-efficacy, and they ran reading comprehension test to measure reading ability. Their results showed that female participants had more positive reading attitude than male ones. The results also showed that the correlation between reading attitude and reading ability was positive, meaning that those with positive attitude toward reading in English had better reading ability. Likewise, reading attitude had a positive correlation with reading efficacy, which means that students with positive attitude toward reading in English had higher level of reading efficacy.

A study by Tercanlioglu (2002-2003) in an EFL setting in Turkey explored the relationship among language learning strategies, reading self-efficacy, and reading comprehension. She conducted the study on 184 pre-service teachers, majoring in English teacher education at a university in Turkey. The participants were at the third year of 4-year study, and their English competence was intermediate. The study produced some results. Firstly, learning strategies variables and reading efficacy variables were correlated one to another. This suggested that those with high self-efficacy would apply various learning strategies in approaching a task. Secondly, language learning strategies were correlated with reading comprehension, suggesting that students with better reading comprehension apply various learning strategies. Finally, there was a significant positive correlation between the students' self-efficacy and reading achievement, where students with high efficacy had higher academic achievements than those with low efficacy.

A problem with the study by Tercanlioglu (2002-2003) was that the reading self-efficacy questionnaire used to measure self-efficacy did not have content validity because they did not measure the students' judgments of their capabilities in reading texts in English and did not specify the activities reflected in reading comprehension.

With EFL/ESL settings, the two studies show the positive relation between reading self-efficacy and reading competence. However, the self-efficacy questionnaires in both studies seem to be inadequate to measure self-efficacy according to the proposed ideals by Bandura (1986). Given more accurate self-efficacy questionnaires, the relations between reading self-efficacy and competence might be stronger. In this study, a more accurate self-efficacy questionnaire was adopted to measure reading self-efficacy in order to evaluate a more reliable and valid relationship between the two variables.

\section{Method}

\subsection{Participants}

One hundred and twenty participants learning English as a foreign language from different language schools in Neyshabur voluntarily participated in this study. The participants were at different age ranges and were selected among those who were at intermediate level of English learning. In this study, the researcher used 65 female and 55 male participants. Their ages ranged from 15 to 24 with the majority of 17 year old participants. The courses they passed at language school and the given language certificates were the criteria for determining the level of their language knowledge. Besides, the participants took a Michigan proficiency test, based on which the participants at the intermediate level of language proficiency were selected.

\subsection{Instruments}

The instruments that were utilized in this study are as the following: 


\subsubsection{The Self-efficacy Beliefs Questionnaire}

Self-efficacy questionnaires are usually developed in each study due to the specificity of the self-efficacy beliefs measured in each study (Smith, Wakely, Kruif, \& Swartz, 2003). So in this research, the researchers used a researcher-designed questionnaire on self-efficacy about reading comprehension. This questionnaire is constructed based on three questionnaires of Beliefs about Language Learning (BALLI), designed by Hortwiz (1985), Persian Adaptation of the General Self-efficacy Scale, constructed by Nezami, Schwarzer, and Jerusalem (1996), and Morgan-Links Student Efficacy Scale (MJSES), written by Jinks and Morgan (1999). The researcher-designed questionnaire consists of 20 Likert-scale items. To ensure the content validity of the measurement, the English Reading Self-Efficacy questionnaire was developed based on suggestions from Bandura (2006) such as using can do statements, reflecting the tasks measured in the reading assessment. This was to make sure that the self-efficacy instrument accurately matched with the performance measures in the reading assessment. Additionally, as suggested by Pajares, Hartley and Valiante (2001), the response scale ranges from zero (cannot do) to hundred (highly certain can do) with 10-point intervals to ensure the sensitivity and predictive ability of the measurement.

The Self-Efficacy belief questionnaire consisted of 20 statements, which reflected the ability of reading in general and the reading tasks in the reading assessments in particular. As an example, one of the required reading tasks is asking the students to find the main idea of the passage. The relevant self-efficacy measure is to ask the students to evaluate their capability to find the main idea from a text. The statements in the self-efficacy measure were developed in this way by the researchers.

In order to assess the content validity of the scale, its items with regard to the definition of the variable were analyzed by three experts. This scale was translated into Persian (the mother tongue of the participants) for the sake of clarity. The questionnaire was piloted on 30 similar participants. Based on their feedback, the questionnaire was revised. To ensure the reliability of the self-efficacy instrument, an internal reliability test (Cronbachs $\alpha$ ) was conducted, and the results (shown in Table 3.1) indicated that the instrument had a high internal consistency. The reliability index was $(\alpha=0.86)$.

Table 3.1 Reliability Index of Self-efficacy Instrument

\begin{tabular}{ll}
\hline Cronbach $\alpha$ & N of Items \\
\hline 0.863 & 20 \\
\hline
\end{tabular}

\subsubsection{Michigan Test}

Michigan Test, as a test of English language proficiency, which comprises of 100 questions, is often used to test students' knowledge in terms of grammar, vocabulary and reading comprehension. In order to determine students' reading comprehension ability, the reading comprehension part of Michigan Test, which comprises of 20 reading comprehension multiple-choice items, was used in this study. This part of the test includes five reading comprehension passages, each followed by four multiple-choice questions.

\subsection{Procedure}

Before distributing the questionnaire to the participants, they were told that their identities would be kept confidential. The participants were briefed on the purpose of the questionnaire, its scope, and its significance for EFL learning. They were asked to answer the demographic questions on the first part of the questionnaire before answering the main questions. The devoted time to answer the questionnaires was 15 minutes. Then, the researcher administered the Michigan reading comprehension test to determine the level of reading proficiency of the participants. The time for responding the reading test was 60 minutes.

\subsection{Design of the Study}

To investigate the research questions in this study, quantitative form of inquiry was utilized. The dependent variable of this study is reading comprehension of Iranian EFL learners. The data of students' English self-efficacy was elicited by a survey instrument. A reading assessment was administered to measure the students' English language reading comprehension. The independent variables of this study are self-efficacy beliefs and gender of Iranian EFL learners. As no experimental treatment was used in this study, the design of the study is ex post facto.

\subsection{Data Analysis}

To answer the research questions, the collected data were analyzed by Statistical Software for Social Sciences (SPSS). The Pearson product-moment formula was applied to answer the first question and an independent T-Test was used to answer the second question. 


\section{Results and Discussion}

\subsection{Overview}

The present study finds significance as it seeks to find out if learners' self-efficacy beliefs are related to their reading comprehension achievement. After administering the questionnaires and test, some statistical analyses were conducted. Following the results section of the study, the researcher discussed the results in the light of the research questions posed in this study.

\subsection{Gender of the Participants}

120 learners learning English as a foreign language from different language institutes in Neyshabur participated in the present study. The researcher tried to have the same number of male and female participants, but the number of female participants was more than the male participants. In this study, the researcher used 65 female and 55 male participants. The learners were at different age ranges and were selected among those who were at intermediate level of English learning. The participants' ages ranged from 15 to 24 with the majority of them were 17 years old. Table 4.1 shows the gender of the participants and their frequency.

Table 4.1 Demographic (Gender) Characteristics of the Participants $(n=120)$

\begin{tabular}{lll}
\hline Gender & Frequency & Percent \\
\hline Female & 64 & 0.53 \\
Male & 56 & 0.47 \\
& & \\
\hline
\end{tabular}

\subsection{First Research Question}

The first research question is concerned with the relationship between EFL learners' self-efficacy and their reading comprehension. To answer the question, the Pearson-product moment formula was applied. Table 4.2 demonstrates the results.

Table 4.2 Pearson Correlations between Self-efficacy and Reading Comprehension

\begin{tabular}{llll}
\hline & & Efficacy & Reading \\
\hline \multirow{2}{*}{ Efficacy } & Pearson Correlation & 1 & $.693^{* *}$ \\
& Sig. (2-tailed) & & .000 \\
& $\mathrm{~N}$ & 120 & 120 \\
& Pearson Correlation & $.693^{* *}$ & 1 \\
Reading & Sig. (2-tailed) & .000 & \\
$\mathrm{~N}$ & & 120 & 120 \\
\hline
\end{tabular}

**. Correlation is significant at the 0.01 level (2-tailed).

Based on the findings shown in Table 4.2, the correlation coefficient between the two variables is 0.69 and is significant at $p<0.01$. Since the correlation is positive, it is postulated that the more self-efficacious the learners are, the better they have answered the reading comprehension questions. The results indicate that there was a significant relation between self-efficacy and reading comprehension. It should be noted that the Pearson values enjoyed large effect sizes.

Based on the scatter plots displayed below (Figure 4.1), it can be claimed that the relationship between self-efficacy and reading comprehension was linear. The spread of dots mainly fell on the diagonal without any apparent rise-and-fall of scores. 


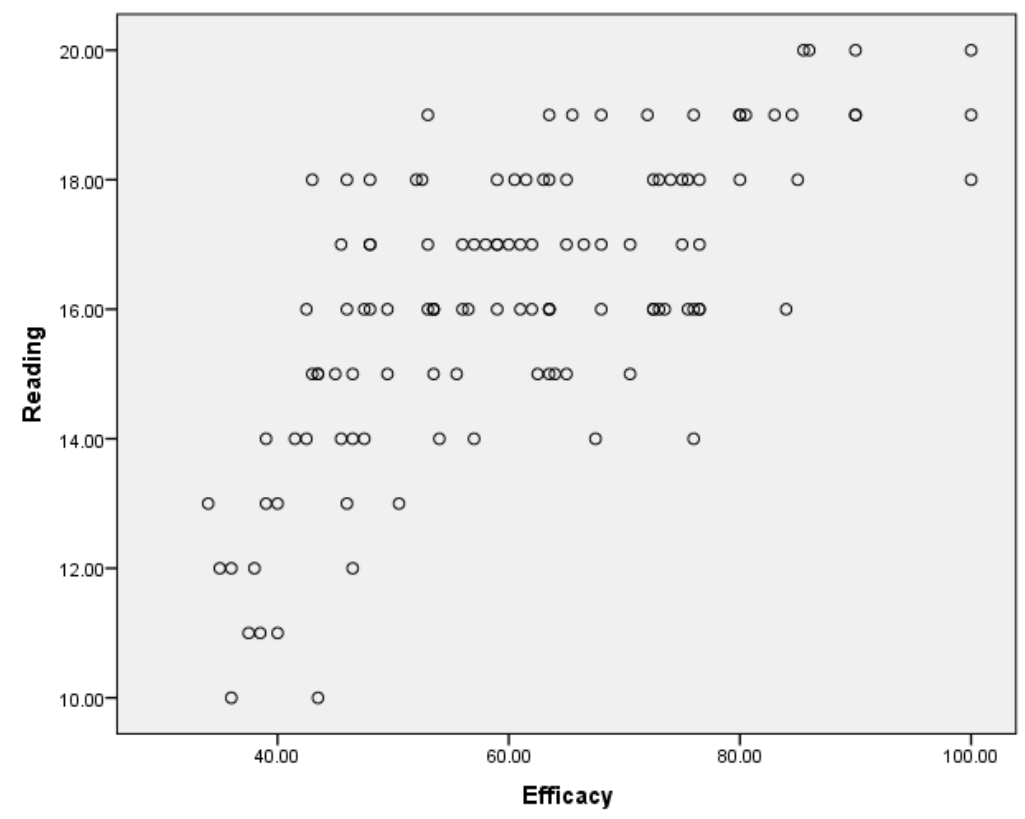

Figure 4.1 Relationships between Reading Comprehension and Self-efficacy

\subsection{Second Research Question}

The second research question is concerned with the relationship between Iranian EFL learners' gender and their self-efficacy beliefs. To answer the question, the researcher applied an independent sample t-test to analyze the collected data. The descriptive statistics of both genders in answering self-efficacy questionnaire is shown in Table 4.3.

Table 4.3 Descriptive Statistics of Self-efficacy Questionnaire

\begin{tabular}{llllllll}
\hline & N & Mean & & $\begin{array}{l}\text { Std. } \\
\text { Deviation }\end{array}$ & Variance & \multicolumn{2}{c}{ Skewness } \\
& Statistic & Statistic & Std. Error & Statistic & Statistic & Statistic & Std. Error \\
\hline Males & 55 & 60.7727 & 1.93435 & 14.34554 & 205.795 & .101 & .322 \\
Females & 65 & 61.2538 & 2.07191 & 16.70426 & 205.795 & .499 & .297
\end{tabular}

According to the findings shown in Table 4.3, the mean score of the male group was 60.77 with the standard deviation of 14.34, and the mean score of the female group was 61.25 with the standard deviation of 16.70 . There were no outliers in the study, so the normality of the data was checked. To check the normality of the data, two measures were used. One was the measure of skewness which needs to be smaller than one to guarantee the normality of the data. The second one was the standard error of skewness. In order to assure normality, the standard error of skewness should be smaller than two. The results are shown in Table 4.4.

Table 4.4 Normality of Self-efficacy Questionnaire Scores

\begin{tabular}{lll}
\hline Gender & Skewness & Std. Error of Skewness \\
\hline Males & 0.101 & 0.322 \\
Females & 0.499 & 0.297 \\
\hline
\end{tabular}

According to Table 4.4, the measure of skewness for the males was 0.101 and for the females was 0.499 , which are both smaller than 1 (skewness $=0.101,0.499<1$ ). The standard error of skewness for the males was 0.322 and for the females was 0.297, which are both smaller than 2 (Std. error of skewness $=0.322,0.297<2$ ). The figure of normal curve distribution of the males and the females can be seen in the Figure 4.2 and Figure 4.3. 


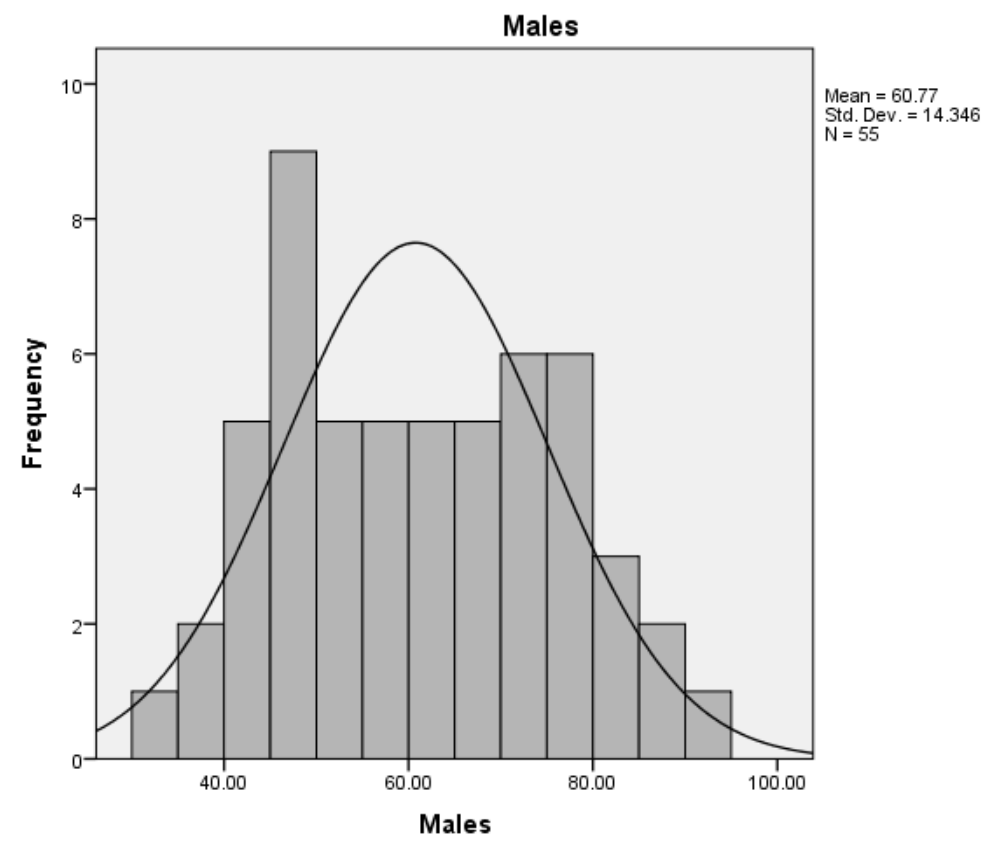

Figure 4.2 The Histogram and Normal Curve Distribution of Self-efficacy Questionnaire for the Males

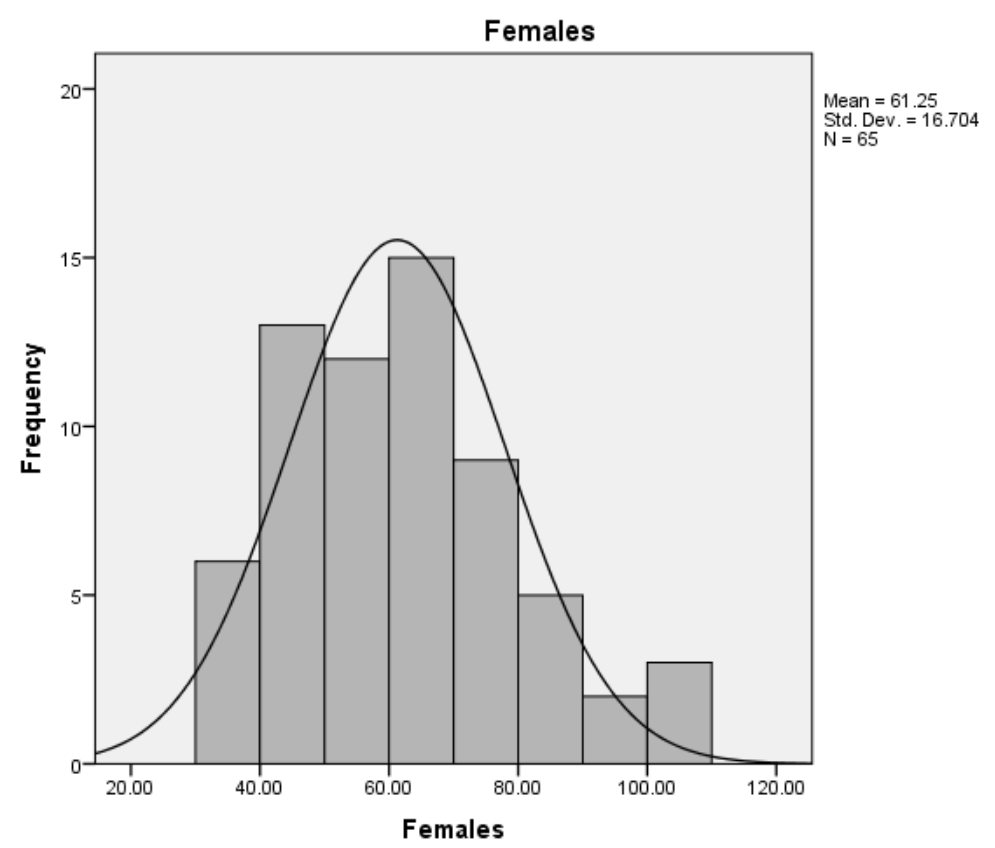

Figure 4.3 The Histogram and Normal Curve Distribution of Self-efficacy Questionnaire for the Females

Since the scores were distributed normally, which met the assumption of normality, a t-test was applied to check whether there was any significant difference between the mean scores of the two groups. The result of the t-test is indicated in Table 4.5. 
Table 4.5 Independent Sample T-test for Comparing the Means of Males and Females

\begin{tabular}{lllllll}
\hline \multicolumn{2}{l}{ Levine's Test for Equality of Variances } & \multicolumn{3}{l}{ t-test for Equality of Means } \\
\hline & $\mathrm{F}$ & Sig. & $\mathrm{t}$ & $\mathrm{df}$ & $\begin{array}{l}\text { Sig. } \\
\text { (2-tailed) }\end{array}$ & $\begin{array}{l}\text { Mean } \\
\text { Differences }\end{array}$ \\
$\begin{array}{l}\text { Equal } \\
\text { variance } \\
\text { assumed }\end{array}$ & 0.31 & 0.57 & 0.168 & 118 & 0.867 & .481 \\
\hline
\end{tabular}

Since the P-value equals to 0.867 , and this is bigger than the level of significance, which is assumed to be 0.05 , the null hypothesis is accepted. This leads to the conclusion that there was no significant difference between Iranian EFL learners' gender and their self-efficacy beliefs. The results of the statistical analysis led the researcher to conclude that the relationship between students' self-efficacy beliefs is not affected by gender.

This section provides a detailed discussion of the findings in the light of the theoretical and empirical studies.

The correlation between Iranian EFL learners' perusing self-efficacy level and reading comprehension was.69 (r =.69). It implies that, there is a significant relationship between students' reading self-efficacy beliefs and their reading comprehension. The findings are in line with the findings of some earlier studies in some aspects. For instance, Rahimi and Abedini (2009) reviewed the part of EFL learner's self-efficacy in regards to listening understanding in their listening test execution. The findings showed that listening comprehension self-efficacy was altogether identified with listening capability. Ghonsooly and Ellahi (2011) showed that EFL learners' self-efficacy is an essential element in the accomplishment of higher scores in English language skills like listening or reading comprehension. The findings are in line with the findings of Salehi and Khalaji (2014) in that there was a significant strong positive correlation between reading self-efficacy beliefs and reading comprehension.

\section{Conclusion and Pedagogical Implications}

It is a common belief that people with higher self-efficacy perform superior to those with lower levels of self-efficacy. As expressed in literature, students with high level of self-efficacy perform superior to those with low level of self-efficacy (Hosenfeld, 1997). Hence, it may be an inquiry whether self-efficacy influences students' performance in language components. As Pajares (2003) and Milles et al (2006) declared, the investigation of the idea of self-efficacy in connection to language accomplishment is still new, and there has been little research in the area in comparison to the work done in different areas. The point of this study was to investigate the impacts of this salient concept on reading comprehension. The reason for exploring self-efficacy as a variable in this study is that self-efficacy beliefs seem to be closely concerned with achievement of students (Chapman \& Tunmer, 2003; Pajares et al, 2001). Schunk (2000) believed that learners' self-efficacies keep their motivation and promotes learning. Concerning the mentioned points, the researchers were motivated to set out the present study to explore the perspectives about learners' ability on reading comprehension in the process of English language learning. There were few studies on the relation between self-efficacy and reading comprehension in EFL field. Conducted in EFL setting in Iran, this study added valuable information to the studies in this field. This study showed that the more self-efficacious the learners are, the better they have answered the reading comprehension questions. There was a significant relation between self-efficacy and reading comprehension. The results of the statistical analysis also led the researcher to conclude that the relation between students' self-efficacy beliefs is not affected by gender.

Although this study has focused primarily on the effects of self-efficacy on reading comprehension of EFL learners, the researcher fully acknowledges that self-efficacy is an extremely complex subject, which is influenced by other factors that are out of control of the researcher such as neurological development, intelligence, home environment, and parental support. However, it is commonly accepted that teaching methods have a significant impact on the learners' development to become a good self-officious reader. As shown in previous studies, self-efficacy seemed to be a consistent variable to predict reading ability. Further studies in different settings would be needed to explore if the use of self-efficacy can contribute to reading ability of other populations. Adding other variables such as English proficiency, passage difficulty, motivation, or personality as independent variables would give more insights to reading ability.

As self-efficacious students will be more motivated, vigorous and persistent in doing tasks (Bandura, 1986), these findings give insights to teachers and educators to the importance of enhancing students' self-efficacy in the academic environment, which in turns can positively impact students' performance. 
Besides teaching the subject matter, teachers can devote considerable time to improve students' self-efficacy by applying some strategies. Since students may find challenging reading texts, higher self-efficacy would even be necessary to ensure that the students would employ greater effort and persistence while facing challenges. Teachers can increase their students' self-efficacy by providing peer modeling in accomplishing tasks. Peer modeling can persuade the students that they can also do the tasks (Ormrod, 2009). It is desirable that teachers use peer models with similar age, or reading ability with the students using such models would give stronger impact on students' self-efficacy.

Teachers can also provide anxiety-reducing strategies that can influence students' affective state, which is one source of self-efficacy belief. Oxford (1990) suggested three affective strategies that could be used in the classroom. Firstly is using music, laughter or relaxation methods to lower anxiety. While a certain level of anxiety can help students reach a good performance, too much anxiety would be harmful for learning because it blocks the learning process. Secondly, is to give encouragements like making positive statements, taking risks wisely and give rewards. Giving encouragements for accomplishments is important strategy to improve self-efficacy as students who receive encouragements score higher in self-efficacy (Jackson, 2002). Finally, teacher can help the students assess their feelings, motivations and attitudes by listening to their body to identify negative or positive emotions. The students can also use a checklist to discover feelings, attitudes and motivation. They can write a language learning diary and discuss their feelings with another person. This set of strategies is helpful for the students to be aware of their anxiety and control their anxiety.

\section{Suggestions for Further Research}

Considering the findings of this study and its limitations, a further research on this topic would be recommended. Studies on similar topic may be conducted by adding more independent variables. Adding other variables such as passage difficulty of the reading texts, motivation, socioeconomic status or students' personalities would be recommended to investigate. Furthermore, a larger sample covering students from different types of school could make future studies more informative and generalizable. Adding other schools such as private schools and bilingual schools would give more thorough information about Iranian high school students' reading ability. Finally, it is recommended that future studies be conducted in experimental design, which explores the effect of reading strategy training on language learners' self-efficacy.

\section{References}

Bandura, A. (1979). Social learning theory. Englewood Cliffs, NJ: Prentice Hall.

Bandura, A. (1986). Social foundations of thought and action: A social cognitive theory. New Jersey: Prentice-Hall, Inc

Bandura, A. (2006). Guide for constructing self-efficacy scales. In F. Pajares \& T. Urdan (Eds.), Self-efficacy beliefs of adolescents, (5), 307-337. Greenwich, CT: Information Age Publishing.

Barkley, R. A. (2006). Attention-deficit hyperactivity disorder: a handbook for diagnosis and treatment. New York, Guilford Press.

Chapman, J.W. \& Tunmer, W.E. (2003). Reading difficulties, reading-related self-perceptions, and strategies for overcoming negative self-beliefs. Reading and Writing Quarterly, 19, 5-24. http://dx.doi.org/10.1080/10573560308205

Delcourt MA, Kinzie MB. (1993). Computer technologies in teacher education: The measurement of attitudes and self-efficacy. Journal of Research and Development in Education, 27, 35-41.

Ehrman, M.L., \& Oxford, R.L. (1990). Adult language learning styles and strategies in an intensive training setting. Modern Language Journal, 74(3), 311-327. http://dx.doi.org/10.1111/j.1540-4781.1990.tb01069.x

Eslami, R. Z., \& Fatahi, A. (2008). Teachers' sense of self- efficacy, English proficiency, and instructional strategies: A study of nonnative EFL teachers in Iran. TESL-EJ Journal, 11(4), 1-19.

Gahungu, O. N. (2007). The relationships among strategy use, self-efficacy, and language ability in foreign language learners. (Doctoral Dissertation), Northern Arizona University.

Graham, S., \& Weiner, B. (1996). Theories and principles of motivation. In D. C. Berliner \& R. C. Calfee (Eds.), Handbook of educational psychology (pp. 63784). New York: Simon \& Schuster Macmillan.

Ghonsooly, B., \& Elahi, M. (2011). Learners' Self-efficacy in Reading and its relation to Foreign Language Reading Anxiety and Reading Achievement. Journal of English Language Teaching and Learning, 53(217). 
Ghonsooly, B., \& Ghanizadeh, A. (2013). Self-efficacy and self-regulation and their relationship: A study of Iranian EFL teachers. The Language Learning Journal, 41(1), 68-84. http://dx.doi.org/10.1080/09571736.2011.625096

Green, J.M., \& Oxford, R. (1995). A closer look at learning strategies, L2 proficiency and gender. TESOL Quarterly, 29(2), 261-297 http://dx.doi.org/10.2307/3587625

Hosenfeld, C. (1977). A preliminary investigation of the reading strategies of successful and non-successful second language learners, System, 5, 110-123. http://dx.doi.org/10.1016/0346-251X(77)90087-2

Horwitz, E. K. (1985). Using student beliefs about language learning and teaching in the foreign language methods course. Foreign Language Annals, 18(4), 333-340. http://dx.doi.org/10.1111/j.1944-9720.1985.tb01811.x

Hsieh, P. P., \& Kang, H. S. (2010). Attribution and Self-Efficacy and Their Interrelationship in theKorean EFL Context.Language Learning, 60(3), 606-627. http://dx.doi.org/ 10.1111/j.1467-9922.2010.00570.

Hsieh, P. H. P., \& Schallert, D. L. (2008). Implications from self-efficacy and attribution theories for an understanding of undergraduates motivation in a foreign language course. Contemporary Educational Psychology, 33, 513-532. http://dx.doi.org/10.1016/j.cedpsych.2008.01.003

Jackson, J.W. (2002). Enhancing self-efficacy and learning performance. The Journal of Experimental Education 70 , 243-55. http://dx.doi.org/10.1080/00220970209599508

Jalilifar, A. R. (2010). Writing titles in applied linguistics: A comparative study of theses and research article. Taiwan ESP Journal, 2(1), 27-52.

Khajavi, Y., \& Ketabi, S. (2012). Influencing EFL Learners ${ }^{e e}$ Reading Comprehension and Self-efficacy Beliefs: The Effect of Concept Mapping Strategy. PortaLinguarum, 17, 9-27.

Lambiotte, J.G., \& Dansereau, D.F. (1992). "Effects of knowledge maps and prior knowledgeon recall of science lecture content", in Journal of Experimental Education, 60(3), 189 - 201.

Linnenbrink, E. A., \& Pintrich, P. R. (2003). The role of self-efficacy beliefs in student engagement and learning in the classroom. Reading and Writing Quarterly: Overcoming Learning Difficulties, 19(2), 119-138. http://dx.doi.org/10.1080/10573560308223

Mills, N., Pajares, F., \& Herron, C. (2006). A Reevaluation of the Role of Anxiety: Self-Efficacy, Anxiety, and Their Relation to Reading and Listening Proficiency. FOREIGN LANGUAGE ANNALS, 39(2), 276-294.http://dx.doi.org/10.1111/j.1944-9720.2006.tb02266.x

Mills, N., Pajares, F., \& Herron, C. (2007). SE of college intermediate French students: relation to achievement and motivation [Electronic version]. Language Learning, 57(3), 417-442. http://dx.doi.org/10.1111/j.1467-9922.2007.00421.x

Multon, K. D., Brown, S. D., \& Lent, R. W. (1991). Relation of self-efficacy beliefs to academic outcomes: A meta-analytic investigation. Journal of Counseling Psychology, 18, 30-38. http://dx.doi.org/10.1037/0022-0167.38.1.30

Naseri, M., \& Zaferanieh, E. (2012). The relationship between reading self-efficacy beliefs, reading strategy use and reading comprehension level of Iranian EFL learners. World Journal of Education, 2, 64-75. http://dx.doi.org/10.5430/wje.v2n2p64

Nezami, E., Schwarzer, R., \& Jerusalem, M. (1996). Persian Adaptation (Farsi) of the General Self-Efficacy Scale. [Online] Available: http://userpage.fu-berlin.de/ health/persean.htm (May 18, 2011).

Nevil, A.M. (2008). The Impact of Reading Self-efficacy and the Regulation of Cognition on the Reading Achievement of an Intermediate Elementary Sample. Unpublished $\mathrm{PhD}$ dissertation. Indiana University of Pennsylvania.

Ormrod, J. (2008). Human learning (3rd ed.). Upper Saddle River, NJ: Prentice-Hall. Retrieved November 2012, from http://teachnet.edb. utexas.edu/ Lynda_abbot/Social.html

Paris, S.G., \& Oka, E.R. (1986). Children's reading strategies, metacognition, and motivation. Developmental Review, 6, 25-56. http://dx.doi.org/10.1016/0273-2297(86)90002-X

Shell, D. F., Murphy, C. C, \& Bruning, R. H. (1989). Self-efficacy and outcome expectancy mechanisms in reading and writing achievement. Journal of Educational Psychology, 81, 91-100. http://dx.doi.org/10.1037/0022-0663.81.1.91 
Oxford, R. L. (1990). Language learning strategies: What every teacher should know. Toronto, Canada: Heinle \&Heinle.

Pajares, F. (2000). Self-efficacy beliefs and current directions in self-efficacy research. From http://www.emory.edu/EDUCATION/mfp/effpage.html

Pajares, F. (2003). Self-efficacy beliefs, motivation, and achievement in writing: A review of the literature. Reading \& writing Quarterly, 19 (2), 139-158. http://dx.doi.org/10.1080/10573560308222

Pajares, F., \& Johnson, M. J. (1996). Self-efficacy beliefs in the writing of high school students: A path analysis. Psychology in the Schools, 33, 1637175.

Pajares, F., Miller, M. D., \& Johnson, M. J. (1999). Gender differences in writing self-beliefs of elementary school students. Journal of Educational Psychology, 91, 50761. http://dx.doi.org/10.1037/0022-0663.91.1.50

Pajares, F., \& Valiante, G. (1997). Influence of writing self-efficacy beliefs on the writing performance of upper elementary students. Journal of Educational Research, 90. http://dx.doi.org/10.1080/00220671.1997.10544593

Pajares, F., Hartley, J., \& Valiante, G. (2001). Response format in writing self-efficacy assessment: Greater discrimination increases prediction. Measurement and Evaluation in Counseling and Development, 33(2), $147-221$.

Pintrich, P. R., \& Schunk, D. H. (2002). Motivation in education: Theory, research, and applications (2nd ed.). Upper Saddle River, NJ: Prentice Hall.

Rahimi, A., \& Abedini, A. (2009). The interface between EFL learners' self-efficacy concerning listening comprehension and listening proficiency. Novitas Royal, 3(1), 14-28.

Rubin, J (1975). What the 'good language learner' can teach us, TESOL Quarterly, 9, 41-51. http://dx.doi.org/10.2307/3586011

Sani, A. M. \&Zain, Z. (2001).Relating adolescents' second language reading attitudes, self-efficacy for reading, and reading ability in a non-supportive ESL setting. The Reading Matrix, 11(3). 243-254.

Schunk, D. H. (1991). Self-efficacy and academic motivation. Educational Psychologist, 26, 207-231. http://dx.doi.org/10.1080/00461520.1991.9653133

Schunk, D. H., \& Pajares, F. (2002). The development of academic self-efficacy. In A. Wigfield \& J. S. Eccles (Eds.), Development of achievement motivation (pp. 15- 31). San Diego: Academic Press. http://dx.doi.org/10.1016/b978-012750053-9/50003-6

Schunk, D. H., \& Rice, J. M. (1984). Strategy self-verbalization during remedial listening comprehension instruction. J. Exper. Educat. 53, 49-54. http://dx.doi.org/10.1080/00220973.1984.10806361

Shell, D. F., Murphy, C. C, \& Bruning, R. H. (1989). Self-efficacy and outcome expectancy mechanisms in reading and writing achievement. Journal of Educational Psychology, 81, 91-100. http://dx.doi.org/10.1037/0022-0663.81.1.91

Smith EV, Jr, Wakely MB, De Kruif REL, Swartz CW. (2003). Optimizing rating scales for self-efficacy (and other) research. Educational and Psychology $\quad$ Measurement. 6, 369-391. http://dx.doi.org/10.1177/0013164403063003002

Tercanlioglu, L. (2002-2003). Strategy use, reading efficacy and academic achievement. Journal of College Literacy and Learning, 31, 53-70.

Tilfarlioğlu, F. T., \& Ciftci, F. S. (2011). Supporting Self-efficacy and Learner Autonomy in Relation to Academic Success in EFL Classrooms (A Case Study). Theory and Practice in Language Studies, 1(10), 1284-1294. http://dx.doi.org/10.4304/tpls.1.10.1284-1294

Wigfield, A., \& Guthrie, J.T. (1997). Relations of children's motivation for reading to the amount and breadth of their reading. Journal of Educational Psychology, 89, 420-432.

Wigfield, A., Guthrie, J. T., Tonks, S., \& Perencevich, K. C. (2004). Children's motivation for reading: Domain specificity and instructional influences. Journal of Educational Research, 97, 299-309. http://dx.doi.org/10.3200/JOER.97.6.299-310

Wu, W.S., Li, W.H. \& Chen, B.S. (2006). Computational reconstruction of transcriptional regulatory modules of the yeast cell cycle. BMC Bioinformatics, 7, 421. http://dx.doi.org/10.1002/9783527622818.ch12 
Zimmerman, B. J. (2000). Attaining self-regulation: A social cognitive perspective. In M. Boekaerts, P. R. Pintrich, \& M. Zeidner (Eds.), Handbook of self-regulation (pp. 13-39). San Diego: Academic Press. http://dx.doi.org/10.1016/B978-012109890-2/50031-7 